\section{Compensation for occupationally acquired COVID-19}

To the Editor: A letter to the Editor of the $S A M J^{[1]}$ published online on 17 March 2020 asked whether coronavirus disease 2019 (COVID19) can be considered as an occupational disease, and if a case for occupationally acquired COVID-19 could be made, who would be responsible for medical and funeral (burial) expenses.

The Compensation Commissioner issued a notice dated 20 March 2020, entitled 'Compensation for Occupationally-Acquired Novel Corona Virus Disease (COVID-19), ${ }^{[2]}$ in terms of the Compensation for Occupational Injuries and Diseases Act No. 130 of 1993 (COIDA). ${ }^{[3]}$ The Commissioner issued a directive that the notice came into effect on the date of publication and will be implemented with immediate effect.

In the notice, occupationally acquired COVID-19 is defined as 'a disease contracted by an employee as defined in the COID Act arising out of and in the course of his or her employment. ${ }^{\text {[2] }}$ An employee who was previously not infected with COVID-19 may acquire COVID-19 as a result of single or multiple exposures in a workplace or after work-related travel to high-risk areas.

For a case to be accepted as occupationally acquired, the following criteria must be met:

- Exposure to COVID-19, in the workplace out of and in the course of employment.

- A clinical diagnosis in accordance with World Health Organization (WHO) guidelines. The notice does not provide a reference to a particular document, but a variety of guidelines are available on the WHO website. ${ }^{[4]}$

- Proof of approved work-related travel to high-risk countries or areas.

- Performing work in an environment with an inherently high risk.

- The development of illness can be chronologically linked to exposure in the workplace.

Physical impairment will be determined 3 months after diagnosis, and when maximal medical improvement is attained. The Commissioner reserves the right to decide whether any permanent disablement is a result of COVID-19.

In all cases accepted by the Commissioner as occupationally acquired, payment for reasonable medical expenses shall be covered by the Compensation Fund for a period not exceeding 30 days from the date of diagnosis. Compensation for additional medical expenses shall be considered if, in the opinion of the Director-General, treatment may reduce the extent of disablement.

The fund will cover burial expenses and widows and dependants' pensions in cases where employees succumb to COVID-19.

In addition to medical expenses, the fund will pay total temporary disability (TTD) benefits where disablement is attributed to a confirmed case of COVID-19. TTD benefits will be applicable for a period not exceeding 30 days from the date of diagnosis.

In suspected or unconfirmed cases, where a medical practitioner recommends self-quarantine in accordance with accepted guidelines, the employer shall be liable for remuneration for sick absenteeism.

Reporting of cases to the Compensation Commissioner must be done in line with the requirements set out in the notice, using the prescribed documentation.

Claims may be submitted online or manually. All claims should reflect the correct 10th revision of the International Statistical Classification of Diseases and Related Health Problems (ICD-10) code, U07.1.

\section{Robin George}

Occupational Health, Momentum Metropolitan Health, Centurion, South Africa

\section{Ann George}

Centre for Health Science Education, Faculty of Health Sciences, University of the Witwatersrand, Johannesburg, South Africa ann.george@wits.ac.za

\footnotetext{
1. George R, George A. COVID-19 as an occupational disease? S Afr Med J 2020;110(4):260. https://do org/10.7196/SAMJ.2020.v110i4.14712

2. Republic of South Africa. Notice on Compensation for Occupationally-Acquired Novel Corona Virus Disease (COVID-19) under Compensation for Occupational Injuries and Diseases Act, 130 of 1993 as amended. 2020. http://www.bkcob.co.za/wp-content/uploads/2020/03/Covid-19-COID-notice.pdf (accessed 22 March 2020).

3. Republic of South Africa. Compensation for Occupational Injuries and Diseases Act, 1993 (Act No. 130 of 1993). Government Gazette No. 15158:1850. 6 October 1993. https://www.gov.za/sites/default/ files/gcis_document/201409/act130of1993.pdf (accessed 22 March 2020).

4. Centers for Disease Control and Prevention. Coronavirus (COVID-19). https://www.cdc.goy/ coronavirus/2019-ncov/index.html (accessed 22 March 2020).
}

S Afr Med J 2020;110(5):338. https://doi.org/10.7196/SAMJ.2020.v110i5.14743 